\title{
Model procesu odnowy organizacyjnej
}

\section{Model of organizational renewal process}

Szymon Cyfert, Kazimierz Krzakiewicz

Uniwersytet Ekonomicznyw Poznaniu, e-mails: s.cyfert@ue.poznan.pl,k.krzakiewicz@ue.poznan.pl

\section{Streszczenie}

Celem artykułu jest przedstawienie propozycji modelu procesu odnowy organizacyjnej. Punktem wyjścia w artykule uczyniono charakterystykę odnowy organizacyjnej, co w dalszej części pozwoliło na zaprezentowanie modelu procesu odnowy organizacyjnej oraz jego elementów składowych.

Słowa kluczowe: odnowa organizacyjna, model procesu odnowy organizacyjnej.

\section{Abstract}

The aim of this paper is to present the proposal of organizational renewal process model. The paper starts with a description of the basis of organizational renewal, which later allows to present an original proposal of organizational renewal process model and its components.

Keywords: organizational renewal, model of organizational renewal process. 


\section{Wstęp}

Przyjęcie leżącego u podstaw teorii ekologii populacji założenia, zgodnie z którym otoczenie dokonuje świadomej selekcji konkurujących przedsiębiorstw, wybierając te podmioty, które są w największym stopniu efektywne i potrafią najlepiej zaspokoić jego potrzeby [Hatch 2002; Morgan 2008], wymusza na zarządzających konieczność ciągłego dopasowywania systemów zarządzania i modeli biznesowych do zmieniających się warunków otoczenia. Pomimo znaczenia permanentnego podnoszenia efektywności organizacji, model odnowy ciągłej można uznać za efektywny wyłącznie z perspektywy zapewniania „bieżącej sprawności” systemu zarządzania i modelu biznesu, natomiast $\mathrm{w}$ razie pojawiania się nieciągłych zmian $\mathrm{w}$ otoczeniu niezbędne staje się odwołanie do modelu odnowy dyskretnej. Konieczność dokonywania wyborów pomiędzy modelami zmian ciągłych i dyskretnych, a także wpływ procesów odnowy organizacyjnej na wzrost poziomu turbulencji w systemie zarządzania, podwyższenie kosztów funkcjonowania i wzrost ryzyka operacyjnego, wskazują na zasadność podjęcia dyskusji nad kształtem modelu procesu odnowy organizacyjnej.

Istota odnowy organizacyjnej. Odnowa organizacyjna stanowi treść, proces i efekt przekształceń kluczowych elementów systemu zarządzania warunkowanych zmianami modelu biznesowego [Bełz 2012; Cyfert, Bełz, Wawrzynek 2014], przy czym tak definiowana odnowa może przybrać jedną z trzech form: utrzymania, adaptacji bądź innowacji [Pöyhönen 2004].
Zastosowanie powyższego podejścia do definiowania istoty odnowy organizacyjnej, wskazujące na konieczność przyjęcia holistycznego podejścia do doskonalenia organizacji, wymusza na zarządzających konieczność realizacji zmian w trzech obszarach organizacji [Cyfert 2012]:

- $\quad$ warstwie definicyjnej, określającej pożądany wzorzec rozwoju organizacji, opisywanej przy wykorzystaniu koncepcji modelu biznesu i strategicznej karty wyników,

- $\quad$ warstwie regulacyjnej, określającej obowiązujące w organizacji standardy i wzorce działań, opisywanej przy wykorzystaniu mechanizmów systemu zarządzania;

- $\quad$ warstwie realizacyjnej, określającej sposoby wykonywania działań operacyjnych, opisywanej przy wykorzystaniu procesów i projektów.

Przyjęcie węższego podejścia, ograniczającego zakres odnowy organizacyjnej wyłącznie do jednego z wyróżnionych powyżej obszarów, ze względu na wysoki poziom ryzyka wystąpienia zjawiska suboptymalizacji, będzie miało nie tyle neutralny, ile negatywny wpływ na skuteczność procesów zmian.

Model procesu odnowy organizacyjnej. Krytyczna analiza podejść do definiowania odnowy organizacyjnej przedstawionych w literaturze przedmiotu, w której wyróżnia się od trzech (P. Ståhle) do ośmiu (D. Hurst) etapów procesów odnowy organizacyjnej, stanowiła podstawę do zaproponowania dziewięcioetapowego modelu procesu odnowy organizacyjnej (rys. 1).

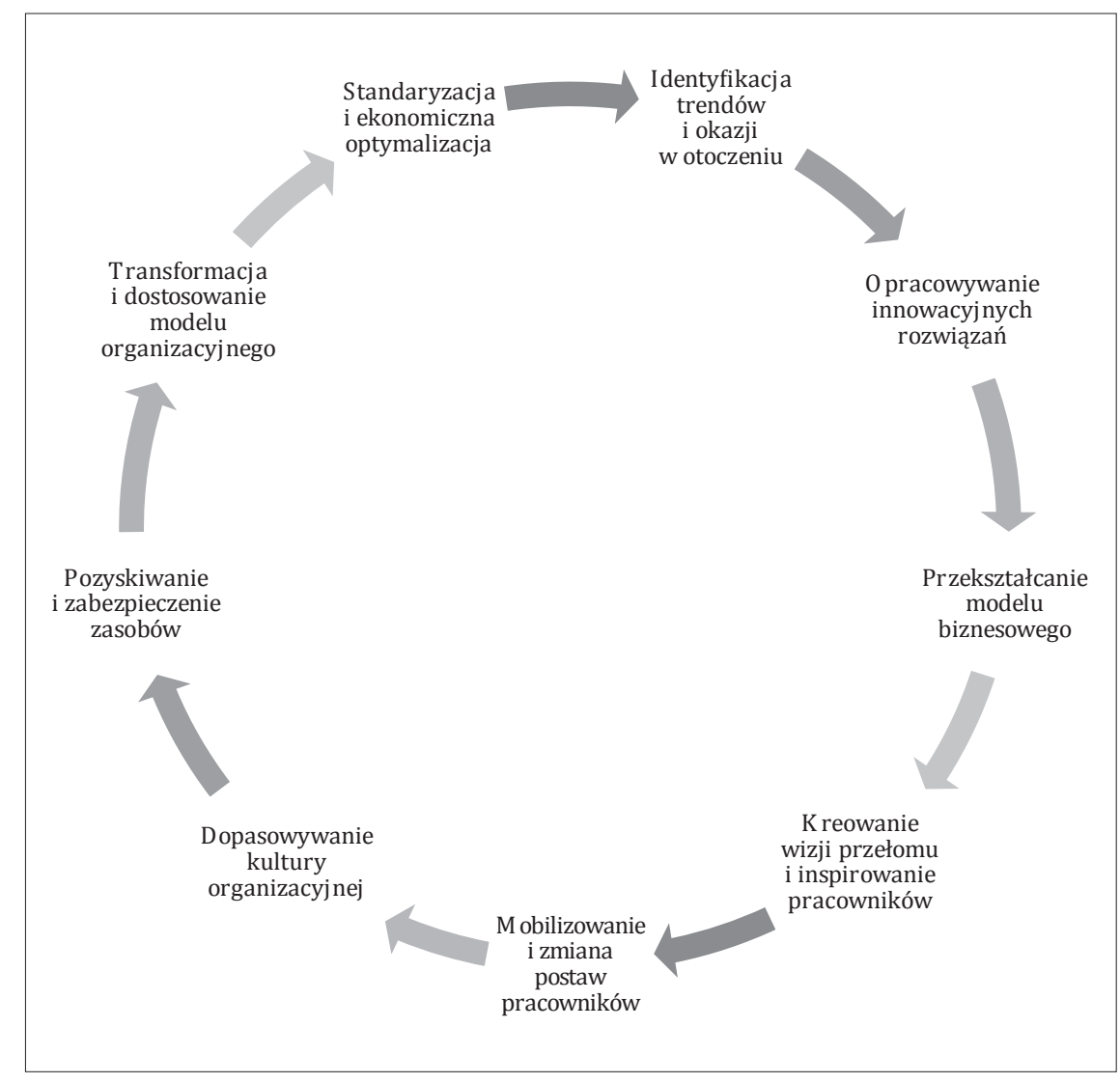

Ryunek. 1. Model procesu odnowy organizacyjnej

Źródło: opracowanie własne. 


\section{Identyfikacja trendów i okazji w otoczeniu}

Punktem wyjścia w procesie odnowy jest opracowanie systemu strategicznego monitoringu otoczenia, pozwalającego na identyfikację procesów zmian w otoczeniu, stanowiących podstawę do oceny poprawności ukształtowania wykorzystywanego w organizacji modelu biznesu.

Zaobserwowane niedopasowanie wykorzystywanego w organizacji modelu biznesu do potrzeb i oczekiwań zgłaszanych przez podmioty w otoczeniu, wskazujące na wykształcenie się luki strategicznej, stanowi impuls do zainicjowania procesu odnowy organizacyjnej. Identyfikacja luki strategicznej zmusza zarządzających organizacją do zredefiniowania kluczowych zasobów, determinujących poziom sprawności procesu odnowy.

Podejmując decyzję o konfiguracji kluczowych zasobów, zarządzający dokonują wyboru pomiędzy procesami rewitalizacji, zasadzającymi się na wykorzystaniu dotychczasowych zasobów, a procesami adaptacji, nakierowanymi na przemodelowanie kluczowych zasobów. W podejściu opartym na rewitalizacji odnowa postrzegana jest jako proces silnie warunkowany dostępem do zasobów, dopasowaniem do norm i standardów w branży oraz podporządkowany wewnętrznym uwarunkowaniom. W konsekwencji zastosowania podejścia opartego na rewitalizacji działania w procesie odnowy nakierowane są na wzmacnianie i wykorzystywanie kluczowych zasobów posiadanych przez organizację. U podstaw podejścia adaptacji leży założenie o konieczności wyjścia poza istniejące wewnętrzne uwarunkowania organizacji, co oznacza, że zwiększenie elastyczności działania organizacji następuje poprzez aktywne poszukiwanie szans $\mathrm{w}$ otoczeniu. Tym samym organizacja zostaje zmuszona do odrzucenia posiadanych zasobów i kluczowych kompetencji, co jest pochodną przyjętego a priori założenia, że organizacje, które odnoszą sukces, uczą się odmiennych zachowań od dotychczasowych i pozyskują nowe kluczowe zasoby [Volberda, Baden-Fuller, Bosch 2001].

Zdiagnozowana luka strategiczna wraz z określoną konfiguracją kluczowych zasobów stanowią podstawę do zdefiniowania i wyboru optymalnego modelu zmian. W zależności od uwarunkowań zarządzający organizacją dokonują wyboru pomiędzy dwoma generycznymi modelami zmian: modelem zmian ciągłych i modelem zmian skokowych [Floyd, Lane 2000]. Podczas gdy procesy odnowy organizacyjnej realizowane w formule zmian ciągłych nakierowane są na bieżące doskonalenie organizacji, zmiany skokowe (dyskretne) oznaczają z perspektywy odnowy organizacyjnej radykalną zmianę, związaną z koniecznością przeprojektowania i wdrożenia kluczowych elementów systemu zarządzania. Zmiany o charakterze dyskretnym, mające na celu szybką przebudowę systemu zarządzania organizacją, mogą stanowić dla organizacji „terapię szokową" [Strebel 1990], która ze względu na swój radykalizm może zostać odrzucona przez system zarządzania organizacji. W celu zapewnienia długookresowego powodzenia organizacji bardziej uzasadnione wydaje się realizowanie procesu odnowy w formule ciągłej, zapewniającej stopniowe wprowadzanie zmian i zrównoważony rozwój organizacji [Agarwal, Helfat 2009]. Zastosowanie takiej formuły zmian pozwoli na uniknięcie zaburzeń w podsystemach organizacji, jednak może doprowadzić do zjawiska „chronicznego nienadążania za zmianami”.

\section{Opracowywanie innowacyjnych rozwiązań}

Określenie modelu odnowy organizacyjnej, optymalnego w aspekcie zidentyfikowanych w otoczeniu trendów i okazji, stanowi punkt wyjścia do podjęcia w organizacji dyskusji nad propozycjami innowacyjnych rozwiązań. Skuteczność procesu odnowy organizacyjnej uzależniona jest zatem od zdolności do przemodelowania systemu zarządzania $\mathrm{w}$ taki sposób, by, sprzyjając organizacyjnemu uczeniu się, umożliwiał generowanie produktywnych idei i nowych pomysłów. Organizacje powinny dążyć do tego, aby stać się liderami idei w swojej branży, aby określać i narzucać innym podmiotom reguły gry, a nie ograniczać swoje możliwości, podążając torem cudzych wyborów strategicznych. Członkowie organizacji muszą mieć zdolność „pozbywania się” nieaktualnej wiedzy, aby pozyskiwać nową, rezygnowania ze dotychczasowych sposobów działania, aby przyswoić sobie nowe wzorce i być gotowymi do podejmowania wyzwań i ciągłych eksperymentów. Menedżerom należy zapewnić takie warunki, aby mogli nieustannie poszukiwać nowych podejść, rozwiązań i metod pracy. Wiedza to jedyny zasób, który powinien reprodukować sam siebie. W sytuacji, w której wiedza deprecjonuje się, erozji ulega także system wartości organizacji, natomiast w sytuacji, w której wiedza jest rozwijana, system wartości jest wzmacniany [Krzakiewicz, Cyfert 2013].

\section{Zmiana i dostosowanie realizowanego modelu biznesowego}

U podstaw procesu odnowy organizacyjnej leży założenie o konieczności holistycznego podejścia do doskonalenia organizacji, co oznacza, że wprowadzanie zmian w systemie zarządzania organizacją musi zostać poprzedzone działaniami związanymi z dopasowaniem modelu biznesowego do procesów zachodzących w otoczeniu. Implementacja zmian w modelu biznesowym stanowi podstawę do wyznaczenia nowego poziomu równowagi organizacyjnej i zdefiniowania warunków brzegowych do realizacji procesów odnowy w warstwach regulacyjnej i realizacyjnej. Wprowadzane w modelu biznesowym zmiany muszą uwzględniać zależności zawiązujące się pomiędzy poszczególnymi składowymi modelu [Falencikowski 2013], nie muszą jednak odnosić się do wszystkich komponentów modelu.

\section{Kreowanie wizji przełomu i inspirowanie pracowników}

Przed przystąpieniem do przekształcania systemu zarządzania niezbędne staje się określenie wizji zmiany oraz zainspirowanie pracowników, stanowiące podstawę do zbudowania poczucia zasadności realizacji przyjętej koncepcji odnowy organizacyjnej.

Definiowanie wizji przełomu w procesie odnowy organizacyjnej jest działaniem iteracyjnym, powodującym, że koncepcja odnowy wyłania się stopniowo. W trakcie poszczególnych iteracji pomiędzy osobami uczestniczącymi w definiowaniu koncepcji odnowy toczy się swoistego rodzaju gra, zmierzająca do zdefiniowania nowego stanu równowagi organizacyjnej. Takie podejście do formułowania wizji zmiany oznacza, że dążenie 
do zapewnienia wysokiego poziomu precyzji w formułowaniu zamierzeń strategicznych, ze względu na ryzyko usztywnienia stanowisk osób wypracowujących rozwiązanie, może przynieść negatywne skutki. Precyzja w definiowaniu procesów zmian stanie się niezbędna na kolejnych etapach, w których zaproponowane zostaną konkretne działania w procesie odnowy organizacyjnej.

Inspirowanie pracowników wymaga od zarządzających odejścia od petryfikacji metod i technik wykorzystywanych w organizacji, bez względu na poziom ich efektywności. Przywódcy powinni skoncentrować się na rzucaniu wyzwań organizacji, a nie na kontrolowaniu jej funkcjonowania, co wymaga od nich dowartościowania procesów stymulowania wyobraźni organizacyjnej i wyrażenia przyzwolenia na eksperymentowanie.

\section{Mobilizowanie i zmiana postaw pracowników}

Propozycje zmian w modelu biznesowym oraz wypracowana wizja przełomu pozostaną abstrakcyjnymi pomysłami dopóty, dopóki nie zostaną w odpowiedni sposób urzeczywistnione. Skuteczni przywódcy, podejmując działania nakierowane na realizację procesu odnowy organizacyjnej, powinni odwoływać się do wiedzy i emocji pracowników - po to, aby ci uwierzyli w realność budowanej wizji i zaangażowali się w jej realizację. Przywódcy muszą mieć świadomość, że emocjonalne zaangażowanie pracowników jest niezwykle ważne dla długofalowego powodzenia organizacji, co oznacza, że powinni kształtować taką kulturę organizacyjną, w której członkowie organizacji będą nie tyle akceptowali pomysły strategiczne, ile wierzyli w skuteczność ich realizacji, zaufają decyzjom menedżerów i uwierzą w sens podejmowanych działań.

Proces odnowy organizacyjnej można zatem traktować w kategoriach rezultatu wyboru, aktu woli, dokonywanego najpierw przez jedną osobę, następnie przez wybraną grupę pracowników organizacji i wreszcie przez krytyczną masę pracowników, którego skuteczność uzależniona jest od akceptacji kierunków zmian w modelu biznesu i systemie zarządzania organizacji. Działania realizowane w fazie mobilizowania umożliwiają sterowanie procesem gromadzenia mentalnej energii, niezbędnej do realizacji i podtrzymania procesu odnowy, pozwalającej na rozszerzenie zakresu akceptacji zmian począwszy od poziomu pojedynczego pracownika, poprzez poziom zespołu, skończywszy na poziomie całej organizacji.

Budowa potencjału przekształcania organizacji wymaga realizacji pięciu powiązanych działań:

1. Kształtowania postaw przywódczych sprzyjających procesom delegowania władzy oraz zapewniających atmosferę zaufania i współpracy.

2. Zbudowania systemu interaktywnej komunikacji wewnątrz organizacji, stanowiącego źródło informacji o działaniach realizowanych $\mathrm{w}$ procesie odnowy oraz umożliwiającego prowadzenie dyskusji nad zasadnością kierunków działań i procesów zmian.

3. Wspierania tworzenia zespołów roboczych, charakteryzujących się interfunkcjonalną reprezentatywnością, sprzy- jającą identyfikacji i rozwiązywaniu problemów związanych z holistyczną, wielowymiarową diagnozą organizacji.

4. Przygotowania uczestników organizacji do wewnętrznego cyklu odnowy, związanego z uświadomieniem znaczenia wprowadzanych zmian i wsparciem w przystosowaniu do nowych warunków działań.

5. Wdrożenia mechanizmów uczenia się i współdzielenia wiedzy w organizacji, zapewniających wykształcenie się nowego zbioru standardów zachowań organizacyjnych, wpływających pozytywnie na skuteczność procesu zarządzana organizacją.

\section{Dopasowywanie kultury organizacyjnej}

Zarządzający organizacjami muszą mieć świadomość, że samego zdefiniowania wizji przełomu nie można uznać za gwarancję skuteczności procesu odnowy organizacyjnej. Kluczem do zapewnienia sukcesu organizacji jest bowiem nie tyle samo określenie wizji, ile prawidłowo realizowany proces jej wdrożenia, w którym to, poprzez dopasowanie poszczególnych składowych organizacji, dąży się do uzyskania i utrzymania efektu synergii. Jeżeli proces dopasowania zostanie przeprowadzony w sposób niewłaściwy, to organizacja, zamiast kreować wartość dodaną, będzie ją niszczyła.

Dopasowanie organizacyjne osiągane jest w wyniku zaakceptowania przez uczestników organizacji systemu norm i wartości, wchodzących w skład kultury organizacyjnej, odnoszących się do współdzielonych poglądów, ideologii, wartości, przekonań i oczekiwań, zbieżnych z wartościami eksponowanymi w strategii. Wewnętrzna spójność owego systemu oraz stopień dostosowania do niego mechanizmów zarządzania wykorzystywanych w organizacji stanowią istotną determinantę efektywności funkcjonowania organizacji. Brak dopasowania mechanizmów zarządzania do kultury organizacyjnej powoduje wykształcenie się zjawiska dysonansu w procesach decyzyjnych, co z kolei prowadzi do obniżenia efektywności funkcjonowania organizacji.

\section{Pozyskiwanie i zabezpieczenie zasobów}

Skuteczność procesu odnowy wymaga podjęcia działań związanych $\mathrm{z}$ pozyskiwaniem, integrowaniem, rekonfiguracją i pozbywaniem się zasobów, pozwalających na zapewnienie dopasowania modelu biznesowego i systemu zarządzania organizacji do dynamicznie zmieniających się warunków otoczenia. Organizacje, wykorzystując dostępne na rynku zasoby, poprzez procesy integracji konstruują z nich odpowiednie kombinacje źródeł unikatowych kompetencji. Jednocześnie, dążąc do zapewnienia stabilności popytu na oferowane produkty $\mathrm{w}$ warunkach permanentnych zmian otoczenia biznesowego, organizacje muszą dysponować odpowiednimi zasobami pozwalającymi na dynamiczne dopasowanie do zmian w otoczeniu. Podejmując próbę generowania wartości z tytułu posiadanych zasobów, organizacja musi adaptować się szybciej i skuteczniej niż konkurenci, co oznacza, że punkt ciężkości w tworzeniu przewag konkurencyjnych położony jest na szybkość reakcji w stosunku do zachowań konkurentów. 


\section{Transformacja i dostosowanie modelu organizacyjnego}

Rekonstrukcja modelu biznesu powiązana ze zmianą postaw pracowników wymaga znalezienia odpowiedzi na pytanie o optymalny, w aspekcie zmian zachodzących w otoczeniu, sposób konstrukcji organizacji. Próba odpowiedzi na tak postawione pytanie związana jest z zaprojektowaniem systemu informacyjnego, systemu komunikacji wewnętrznej, systemu controllingu, systemu motywacyjnego oraz struktury organizacyjnej.

\section{Standaryzacja i ekonomiczna optymalizacja}

Ostatnim etapem w procesie odnowy organizacyjnej jest standaryzacja i ekonomiczna optymalizacja. Działania podejmowane na tym etapie związane są $\mathrm{z}$ zapewnieniem spójności warstwy realizacyjnej z warstwą definicyjną i regulacyjną i nakierowane są na przeprojektowanie architektury procesów oraz zdefiniowanie inicjatyw strategicznych.

\section{Podsumowanie}

Definiując pojęcie odnowy organizacyjnej w opracowaniu, przyjęto, iż stanowi ona treść, proces i efekt przekształceń kluczowych elementów systemu zarządzania warunkowanych zmianami modelu biznesowego, jednocześnie założono, iż procesy odnowy organizacyjnej wymuszają przemodelowanie zarówno systemu zarządzania organizacją, modelu biznesowego, jak i warstwy realizacyjnej organizacji. Powyższe założenia, wyznaczające ramy (dla) realizacji odnowy organizacyjnej, stanowiły podstawę do zaprojektowania dziewięcioetapowego modelu procesu odnowy organizacyjnej, obejmującego następujące etapy: (1) Identyfikacja trendów i okazji w otoczeniu; (2) Opracowywanie innowacyjnych rozwiązań; (3) Przekształcanie modelu biznesowego; (4) Kreowanie wizji przełomu i inspirowanie; (5) Mobilizowanie i zmiana postaw pracowników; (6) Dopasowywanie kultury organizacyjnej; (7) Pozyskiwanie i zabezpieczenie zasobów; (8) Transformacja i dostosowanie modelu organizacyjnego; (9) Standaryzacja i ekonomiczna optymalizacja.

\section{Literatura}

Agarwal R., Helfat C.E., 2009, Strategic renewal of organizations, Organization Science, 20 (2), s. 281-293.

Bełz G., 2012, Potencjał dostosowawczy w procesach odnowy przedsiębiorstw, Przegląd Organizacji, nr 11.

Cyfert Sz., 2012, Systemowy model organizacji: perspektywa procesów odnowy organizacyjnej, [w:] Strategie i mechanizmy odnowy przedsiębiorstw, G. Bełz, Sz. Cyfert (red.), Wyd. Uniwersytetu Ekonomicznego we Wrocławiu, Wrocław.

Cyfert Sz., Bełz G., Wawrzynek Ł., 2014, Wpływ burzliwości otoczenia na efektywność procesów odnowy organizacyjnej, Organizacja i Kierowanie, nr $1 \mathrm{~A}$.

Falencikowski T., 2013, Spójność modelu biznesu. Koncepcja i pomiar, CeDeWu, Warszawa.

Floyd S.W., Lane P.J., 2000, Strategizing throughout the organization: Managing role conflict in strategic renewal, Academy of Managerial Review, 25, s. 154-177.

Hatch M.J., 2002, Teoria organizacji, Wyd. Naukowe PWN, Warszawa.

Hurst D, 1995, Crisis and renewal: Ethical anarchy in mature organizations, Business Quarterly, 60 (2).

Junell J., Ståhle P., 2011, Measuring organizational renewal capability: Case training service business, Competitiveness Review: An International Business Journal, 21 (3).

Krzakiewicz K., Cyfert Sz., 2013, Role przywódców w zarządzaniu innowacjami, [w:] Innowacje w zarządzaniu, J. Skalik, A. Zabłocka-Kuczka (red.), Wyd. Uniwersytetu Ekonomicznego we Wrocławiu, Wrocław.

Morgan G., 2008, Obrazy organizacji, Wydawnictwo Naukowe PWN, Warszawa 2008.

Pöyhönen A., 2004, Modelling and measuring organizational renewal capability, Lappeenranta, Acta Universitatis Lappeenrantaensis 200, Digipaino.

Strebel P., 1990, Dealing with discontinuities, European Management Journal, 8, s. 434-442.

Volberda H.W., Baden-Fuller Ch., Bosch F.A.J., 2001, Mastering strategic renewal: Mobilising renewal journeys in multi-unit firms, Long Range Planning, 34 (2). 